\title{
Middle and Late Pleistocene terrestrial snails from the Middle Dniester area, Ukraine (based on Mykola Kunytsia's collections)
}

\author{
Yana POPIUK ${ }^{1}$, Bogdan RIDUSH ${ }^{1, *}$ and Tatiana SOLOVEY ${ }^{2}$ \\ 1 Yuriy Fed'kovych Chernivtsi National University, Kotsubynskogo 2, 58012 Chernivtsi, Ukraine \\ 2 Polish Geological Institute - National Research Institute, Rakowiecka 4, 00-975 Warszawa, Poland
}

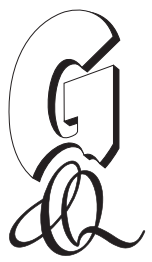

Popiuk, Y., Ridush, B., Solovey, T., 2021. Middle and Late Pleistocene terrestrial snails from the Middle Dniester area, Ukraine (based on Mykola Kunytsia's collections). Geological Quarterly, 65: 6, doi: 10.7306/gq.1575

\begin{abstract}
Extensive collections of land molluscs from the many sections of Middle and Late Pleistocene deposits in the region of the Middle Dniester River were made by Professor Mykola Kunytsia (1925-2002). These collections, now at the Natural Museum, Yuriy Fedkovych Chernivtsi National University, were for the most part analysed, but remained partially unpublished. M. Kunytsia used them for regional reconstructions of palaeolandscapes during various stages of the Pleistocene. In our study, we used these collections to assess the land snail diversity in the region during consecutive stages of the Middle and Late Pleistocene. Our analysis of faunas of cold and warm stages showed that the latter were more diverse. While all or most of the cold stages had many species in common, the faunas of the warm stages were more heterogeneous. Such a feature may play an essential role in Quaternary biostratigraphy.
\end{abstract}

Key words: Middle Dniester, terrestrial molluscs, biodiversity, Pleistocene.

\section{INTRODUCTION}

Due to its numerous well-explored Quaternary sequences, the Middle Dniester region can be regarded as on one of the key territories for Quaternary studies in Eastern Europe. The region covers the canyon-like part of the Dniester River valley, approximately between towns of Halych and Rybnytsia, including canyon-like sections of the Dniester tributaries. In this region, the Dniester valley is quite deep (270-300 m), and wide, with a well-developed succession of ancient river-terraces. Most of the Late and Middle Pleistocene terraces are located inside the deep and narrow canyon-like part of the valleys; however, some high terraces of the Early Pleistocene and Pliocene are wide and developed outside the canyon (Ridush and Marchuk, 2018).

Different authors have identified various numbers of terraces in the Dniester valley, from 6 to 13 (Tomeniuk, 2010). Based on a palaeopedological method, Veklitch (1982) distinguished 16 terraces above the modern floodplain. His approach was adopted by the State Geological Survey of Ukraine.

The general pattern of the Dniester valley looks like a series of huge, deeply incised meanders. As a rule, the inner-canyon Pleistocene terraces, numbered from 1st to 10th, and from 10 to $100 \mathrm{~m}$ high above the modern water table, are preserved on

\footnotetext{
* Corresponding author, e-mail: b.ridush@chnu.edu.ua
}

Received: July 6, 2020; accepted: November 8, 2020; first published online: January 25, 2021 the convex sides of the meanders, while the concave bank of the river is usually steep. Overall, these terraces have a two-fold structure, consisting of an alluvial suite, resting on the bedrock basement, and a sub-aerial suite, comprising slope and aeolian deposits. Both alluvial and sub-aerial suites contain rich faunas of terrestrial snails.

The middle section of the Dniester River valley is famous for its numerous Palaeolithic sites associated with the Pleistocene loess-palaeosol sequences of the ancient river terraces (e.g., Goretsky and Tzeitlin, 1977; Goretsky and Ivanova, 1982; Ivanova and Tzeitlin, 1987; Anisyutkin, 2013; Kulakovska et al., 2015; Łanczont and Madeyska, 2015). Almost all strata of these sequences contain shells of terrestrial molluscs which have traditionally been used for the palaeoecological reconstructions. A number of scholars have studied the Pleistocene snail faunas since 1880 (Dunikowski, 1880; Bąkowski, 1880, 1881, 1884, 1885, 1891; Łomnicki, 1886, 1887, 1900, 1908; Teisseyre, 1900; Friedberg, 1906; Wiśniewski, 1908; Rogala, 1907; Rychlicki, 1913; Polianskyi, 1925; Petrbok, 1930; Ambrozewicz, 1932, 1938; Lungersgauzen, 1933, 1938; Bondarchuk, 1933, 1959; Danilovskyi, 1940, 1961; Berg, 1946; Radzijevskyi, 1957, 1959; Veklitch, 1961, 1968; Ivanova, and Popov, 1961; Kunytsia, 1964, 1965, 1966, 1968, 1969, 1971, 1974, 1975, 1978; Melnychuk, 1972, 1984, 2004; Motuz, 1977, 1982, 1987; Dmytruk, 1998, 2000, 2001).

The greatest contribution to the study of the Pleistocene malacofauna of the region was made by prof. Mykola Kunytsia (1925-2002). His summarising research, which covered almost all the territory of Ukraine, was published a few years after his death. He collected and studied molluscs of the different Pleistocene lithological-stratigraphic units, identified the species, provided a palaeontological-stratigraphic correlation and traced 
zonal-geographical changes of the malacofauna. He was the first to reconstruct palaeolandscapes and palaeoclimates of the glacial and interglacial phases based on ecological-zoogeographical analysis and to prepare palaeolandscape maps of Ukraine (Kunytsia, 2007). Most of Kunytsia's sites were located in the Middle Dniester region.

Most of previous studies of the mollusc assemblages of the region had used them for palaeoecological reconstructions, as temperature and humidity indicators. Our paper focuses on their species diversity, and on identifying common or distinctive features of the Middle and Late Pleistocene mollusc faunas of the region.

\section{MATERIAL AND METHODS}

The mollusc diversity analysis was based on the abundant material published by Kunytsia $(1965,1966,1971,1974,1984$, and 2007), as well as on his unpublished collections. The list of species was supplemented with data of other researchers (Motuz, 1977, 1982, 1987; Melnychuk, 1984, 2004; Dmytruk, 2004; Bogucki et al., 2011, 2012; Alexandrowicz et al., 2014; Alexandrowicz, 2015a, b).

In the biodiversity analysis, in the determination of changes in species composition at different stages of the Pleistocene (Table 1), and in the interpretation of palaeoecological conditions, we specified the most common species which were present at more than one site. To avoid interpretation errors and to exclude random finds, we excluded from the analysis species which were represented at single sites only. Such finds may indicate local differences or re-deposition and require further verification.

Despite the great number of publications dealing with the malacofauna of the region, not all of them specify the exact stratigraphic position of the samples, and this is often true also of Kunytsia's research. In some other publications, some spe-

Table 1

Main stratigraphic units of the Middle and Late Quaternary in Eastern and Western Europe (compiled after Lindner et al., 2004; Lisiecki and Raymo, 2005; Gerasimenko, 2010a; Velichko et al., 2011)

\begin{tabular}{|c|c|c|c|c|c|c|c|c|c|}
\hline$\underset{\substack{E \\
\omega}}{\stackrel{\tilde{D}}{\omega}}$ & . & 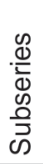 & \multicolumn{2}{|r|}{ Western Europe } & Poland & Ukraine & $\begin{array}{l}\text { Eastern } \\
\text { Europe }\end{array}$ & $\begin{array}{l}\text { Lower } \\
\text { boundary } \\
\text { (ka) }\end{array}$ & MIS \\
\hline \multirow{23}{*}{ 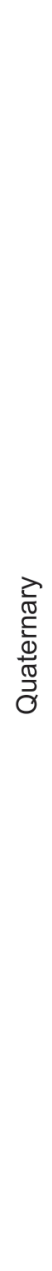 } & \multicolumn{4}{|c|}{ Holocene } & Holocene & Holocene & Holocene & 11.7 & 1 \\
\hline & \multirow{22}{*}{ 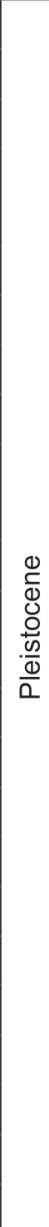 } & \multirow{8}{*}{$\begin{array}{l}\frac{1}{\Phi} \\
\stackrel{\circ}{2}\end{array}$} & \multirow{7}{*}{ 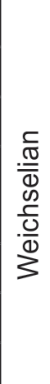 } & Weichselian & \multirow{3}{*}{$\begin{array}{l}15 \\
18\end{array}$} & Prychornomorya (pč) & \multirow{7}{*}{ Valday } & 15 & \multirow{3}{*}{2} \\
\hline & & & & Bölling-Alleröd & & Dofinivka (df) & & 18 & \\
\hline & & & & LGM & & Bug (bg) & & $29(27)$ & \\
\hline & & & & $\begin{array}{c}\text { Moershoofd-Hengelo- } \\
\text { Denekamp }\end{array}$ & $\begin{array}{l}27(29) \\
59(55)\end{array}$ & Vytachiv (vt) & & $59(55)$ & 3 \\
\hline & & & & Schakholz & \multirow{3}{*}{$\begin{array}{c}104 \\
110(116)\end{array}$} & Uday (ud) & & $71(74)$ & 4 \\
\hline & & & & Odderade-Rederstal & & Pryluky (pl) & & $110(104)$ & $5 a-b$ \\
\hline & & & & Brørup-Herning & & Tiasmyn (ts) & & $110(116)$ & $5 c-d$ \\
\hline & & & \multicolumn{2}{|r|}{ Eemian } & Eemian & Kaydaky (kd) & Mikulino & $127(130)$ & $5 e$ \\
\hline & & \multirow{14}{*}{$\frac{\frac{0}{\overline{0}}}{\frac{0}{2}}$} & \multirow{5}{*}{ 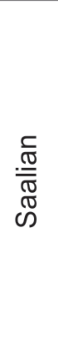 } & Drenthe+Warte III & Odranian + Warte & $\begin{array}{c}\text { Dnieper (dn) } \\
\text { (Dnieper 2) }\end{array}$ & Moscovian & $180(191)$ & 6 \\
\hline & & & & Schöningen & Lubavian & Potyagaylivka & Odintsovian & $230(243)$ & 7 \\
\hline & & & & $\begin{array}{l}? \\
\text { II }\end{array}$ & Krznanian & $\begin{array}{c}\text { Oril (or) } \\
\text { (Dnieper 1) }\end{array}$ & Dnieprovian & $250(300)$ & 8 \\
\hline & & & & Reinsdorf & Zbójnian & \multirow{3}{*}{ Zavadivka (zv) } & Kamenka & (337) & 9 \\
\hline & & & & Fuhne & Liviecian & & $?$ & $(374)$ & 10 \\
\hline & & & & Holstenian & Mazovian & & Likhvin & $410(424)$ & 11 \\
\hline & & & & Elster 2 & Sanian 2 & Tiligul (tl) & Oka Glaciation & $500(478)$ & 12 \\
\hline & & & \multirow{7}{*}{ 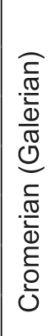 } & IV & Ferdynandovian 1 & Lubny $\left(\mathrm{Ib}_{3}\right)$ & \multirow{3}{*}{ Muchkapian } & $(524)$ & 13 \\
\hline & & & & Glacial C & Ferdynandovian $1 / 2$ & Lubny $\left(\mathrm{Ib}_{2}\right)$ & & $(563)$ & 14 \\
\hline & & & & III & Ferdynandovian 3 & Lubny $\left(\mathrm{lb}_{1}\right)$ & & $600(621)$ & 15 \\
\hline & & & & Glacial B (Elster 1) & Sanian 1 & Sula & Don Glaciation & $650(676)$ & 16 \\
\hline & & & & \multirow{3}{*}{ II } & \multirow{3}{*}{ Małopolian } & Martonosha $\left(\mathrm{mr}_{3}\right)$ & Iljinka & $(712)$ & 17 \\
\hline & & & & & & Martonosha $\left(\mathrm{mr}_{2}\right)$ & Pokrovka & $(761)$ & 18 \\
\hline & & & & & & Martonosha $\left(\mathrm{mr}_{1}\right)$ & ? & $780(790)$ & 19 \\
\hline
\end{tabular}

\footnotetext{
* The age in ka is given for stages after Gerasimenko (2010a) and after Lisiecki and Raymo (2005) for MIS
} 
cies are largely assigned to MIS 2-4 (Alexandrowicz et al., 2014). We used that part of the material which was unambiguously assigned to particular stratigraphic levels and ages within the deposits.

The comparative analysis and assessment of biodiversity of the Pleistocene mollusc assemblages was carried out separately for cold and warm stages. It was found that the frequent climate changes led to ecological and geographical variability of snail assemblages at different stages. Primarily, this concerns changes in the species composition of mollusc assemblages in the warm and cold stages of the Pleistocene (glacials and interglacials)

The faunas of the cold and warm stages differed significantly. However, the species' composition could also vary among the faunas of warm and cold phases. Such variations depended mainly on the temperature, humidity, duration of individual cold or warm stages, and the cyclic nature of climate changes within those stages, as well as on the ability of some species to survive climate change, adapt, and reappear in subsequent stages as relict forms. The interaction of all these factors should be reflected in the individual features of mollusc assemblages at different stages. Because of this, we considered it appropriate to compare the diversity of molluscs separately in cold and warm stages. It is such comparisons that should allow us to specify the differences in the taxonomic and ecological composition of small-scale units of different ages.

Ecological classification of the species was based on Alexandrowicz and Alexandrowicz (2011), detailing malacological analysis, research methods, processing, and interpretation of subfossil mollusc assemblages. The inferred environmental conditions of the Pleistocene stages based on the mollusc assemblages of the region were compared with the results of palaeo-palynological reconstructions of the Pleistocene (Gerasimenko, 2010a).

Apart from Kunytsia's publications, much material accumulated during his lifetime long remained unpublished. Most was deposited at the Natural Museum, Yuriy Fedkovych Chernivtsi National University, more than 15 years ago. They are of considerable value and analysing them is important for Quaternary malacology. Some of the material originates from land now flooded by the Dniester reservoir, and so their presence and significance are especially relevant. We are the first to analyse Kunytsia's unpublished materials. The work was carried out in several stages, which included cataloguing of the material, its curation and identification. Overall, the collection consists of 897 glass tubes containing mollusc shells from different regions of Ukraine, which we sorted by locality. The most abundant material come from the Middle Dniester valley, and only molluscs from that area are described in this paper.

The labels mostly pertain to the geographical location (nearest town or village in whose vicinity the sampled geological section was situated); sediments in the sections; mollusc species identified; rarely, detailed geographic reference of the section relative to the town or village; and depth of sampling in the section. Overall, more than 458 glass tubes with subfossil material are from the middle part of the Dniester valley. Unfortunately, many of the tubes do not bear any indication of the location, or just give the number of the section (for example, section 226 'P. 226'). The information regarding such samples was contained in Kunytsia's diaries, which are lost.

We were able to reconstruct information concerning a number of localities (Fig. 1; 1-43); these include sections in the villages of Ataky (19 samples), Rukhotyn (5 samples), Gorodok (6 samples), Dnistrove (8 samples), Isakivtsi (5 samples), Zavallya (2 samples), Kudryntsi (4 samples), Kamyanka (4 samples), Naddnistrianka (26 samples), Smotrych (27 sam- ples), Teremtsi (8 samples), Stara Ushytsia (15 samples), Molodove (29 samples), Repuzhyntsi (29 samples), Zalishchyky (30 samples), Ozhevo (59 samples), Lypchany (54 samples), Vasylivka (20 samples), Voloshkovo (45 samples), Nezvysko (19 samples) and Halych (31 samples).

The following species are represented in the samples from these localities: Acicula polita, Carychium minimum, Succinea oblonga, S. o. elongata, S. putris, Cochlicopa lubrica, C. nitens, Acanthinula aculeata, Vallonia costata, V. pulchella, $V$. enniensis, $V$. tenuilabris, Pupilla muscorum, $P$. loessica, $P$. sterri, Vertigo pygmaea, V. parcedentata, $V$. angustior, Columella edentula, C. columella, Orcula dolium, Chondrula tridens, Cochlodina laminata, Clausilia dubia, Cl. cruciata, Laciniaria plicata, Vitrea crystallina, Nesovitrea hammonis, Euconulus fulvus, Trichia hispida, Helicopsis striata, Xerolenta obvia (= Helicella candicans), Perforatella bidentata, Pseudotrichia rubiginosa, Euomphalia strigella, Cepaea vindobonensis, Helix đomatia, Theodoxus fluviatilis, Fagotia acicularis, Bithynia tentaculata, Lithoglyphus naticoides, Lymnaea (Stagnicola) palustris, Physa fontinalis, Anisus spirorbis, Pisidium casertanum. Many samples have not yet been identified and require further research.

Since the stratigraphic position of some samples remains unknown, not all species from the collection are included in our analysis. However, information on the location of the sections makes it possible to re-sample the sites in the future, to refine the data.

\section{RESULTS}

The Pleistocene climate changes involved a succession of cold and warm phases of different amplitude. It is obvious that the mollusc faunas of cold and warm phases were quite different, but even mollusc assemblages among the cold and warm phases varied considerably; that is why we analyse the mollusc diversity separately for the cold and warm phases.

An essential feature of molluscs during the cold phases is their adaptation to climate changes, as expressed by morphological changes in the shell size and structure: aperture size, shell thickness, presence of apertural barriers etc. As noted by Kunytsia (1966), the shells of ubiquitous species of prolonged cold phases differ from those of warm stages in marked traces of adverse habitat effects. For example, terrestrial species have smaller shells (some being dwarfed) compared with typical specimens, possess a diminutive aperture, are thin-walled in areas close to the ice front and thickened on calcium-rich calcareous deposits. Freshwater snails in cold conditions are relatively small and have thickened shell walls. Such variation serves as an effective basis for the reconstruction of climate conditions not only in the case of stenoecious species, but also for euryoecious snails. Climate changes were also reflected in the species composition of the Pleistocene mollusc assemblages and their geographical distribution at different climatic stages. All these patterns are well-reflected in the assemblages from the Middle Dniester region.

Within this region, species assemblages of different warm phases are more different than those of different cold phases, while individual features are clearly manifested in some intervals. This specificity of interglacial faunas has also been noted for northwestern Europe (Limondin-Lozouet and Preece, 2014). This is due to the more significant variability of the landscapes during the warm stages.

Our studies show that the ubiquitous Succinea oblonga was common throughout the Pleistocene, both in the cold/warm, and in the dry/wet phases. Typical cold-loving species which 

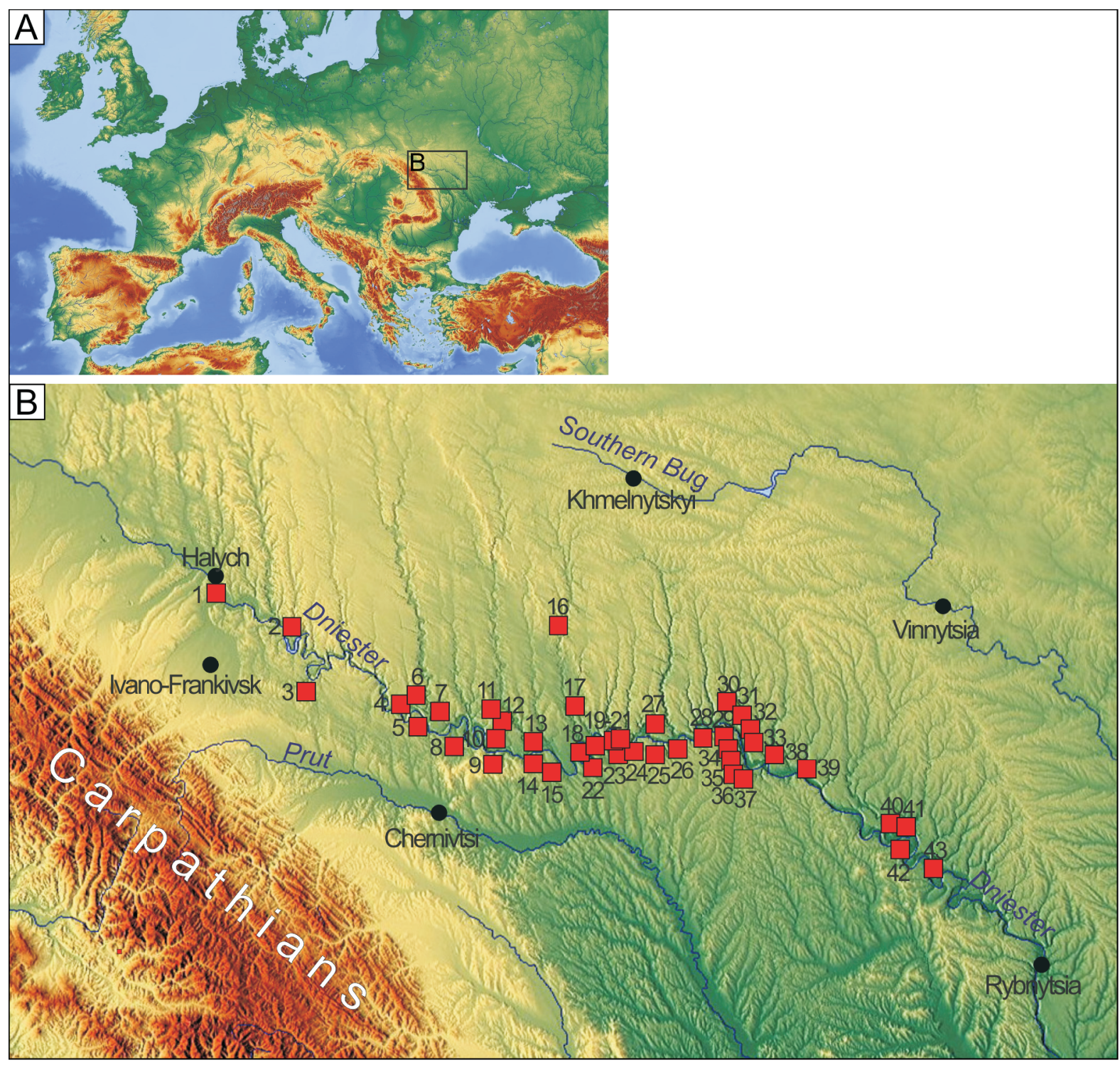

Fig. 1. Pleistocene sites with mollusc faunas in the Middle Dniester valley (according to unpublished materials by M. Kunytsia)

1 - Halych, 2 - Koropets, 3 - Nezvysko, 4 - Zalishchyky, 5 - Repuzhyntzi, 6 - Dobrovliany, 7 - Horodok, 8 - Onut, 9 - Rukhotyn, 10 - Dnistrove, 11 - Kudryntsi, 12 - Zavallya, 13 - Isakivtsi, 14 - Ataky, 15 - Hotyn, 16 - Smotrych, 17 - Kamianka, 18 Voronovytsia, 19 - Makarivka, 20 - Nagoriany, 21 - Hrushivtsi, 22 - Lenkivtsi, 23 - Babyn, 24 - Dnistrivka, 25 - Molodove, 26 Korman, 27 - Stara Ushytsia, 28 - Neporotove, 29 - Lomachyntsi, 30 - Naddnistrianske, 31 - Zhvan, 32 - Bernashivka, 33 Lypchany, 34 - Ozheve, 35 - Vasylivka, 36 - Rozpopyntsi, 37 - Voloshkovo, 38 - Yaryshiv, 39 - Mogyliv-Podilskyi, 40 - Bila, 41 - Porogy, 42 - Kosoutsy, 43 - Velyka Kisnytsia

occurred throughout all the cold phases of the Pleistocene are Columella columella and Vallonia tenuilabris (Kunytsia, 1965, 1966, 1971, 1974, 1984, 2007; Motuz, 1977, 1982, 1987; Melnychuk, 1984, 2004; Dmytruk, 2001; Bogucki et al., 2002, 2004; Alexandrowicz et al., 2014). Xerolenta obvia (= Helicella candicans) is thermophilous. However, it sometimes appears in the cold intervals, and this is clearly due to the aridity because it is also associated with xeric habitats. Despite the comparatively uniform composition of snail assemblages of the cold phases, there are some phase-to-phase differences.

Malacofaunas of the cold stages of the Middle and Late Pleistocene and their diversity

The Sula Stage (650-600 ka, MIS 18) is distinguished by a considerable species diversity (Table 2). Typical species of this stage do not occur in the succeeding cold Pleistocene periods:
Vertigo aff. ronnebyensis, Vallonia pulchella, V. enniensis, Cochlicopa lubrica, Nesovitrea petronella. Two species in the middle Dniester valley, Vertigo alpestris and Vertigo genesii, have been found only in Sula and Bug loesses.

The fauna of the Sula stage has a specific ecological and zoogeographical composition. The assemblage includes species of different habitat preferences, while mostly cold-loving or cold-resistant. Besides the predominance of mesophiles, hygrophiles and psychrophiles are present (Vertigo genesii, Vallonia enniensis, Pseudotrichia rubiginosa); they prefer moist areas and possibly even wetlands. Alexandrowicz (2015a) noted that assemblages with Vertigo genesii are characterized by the presence of many moist-loving and cold-loving species. The fauna of this stage includes also numerous xerophiles (Pupilla sterri, P. triplicata, Chondrula tridens, Xerolenta obvia 
(= Helicella candicans); there are many species of open habitats (Vertigo parcedentata, Pupilla muscorum, P. densegyrata, P. sterri, P. triplicata, Vallonia pulchella, V. tenuilabris), and typical forest-dwellers (Vertigo aff. ronnebyensis). Such a diverse set of species in the context of ecological conditions suggests that during the $50 \mathrm{ky}$ of the Sula Stage (650-600 ka) (Gerasimenko, 2010a), within the Middle Dniester area, several assemblages successively developed, often regarded as one taphocoenosis. The vertical facies variation of the deposits, and of those assemblages, shows that the beginning of the Sula Stage was rather cold and relatively humid, and its later phase was cold and dry (Kunytsia, 1974). This is supported by the palynological data, according to which two cold sub-stages $\left(\mathrm{sl}_{1}\right.$ and $\mathrm{sl}_{2}$ ) and one relatively warm stage $\left(\mathrm{sl}_{3}\right)$ occurred in Sula time (Gerasimenko, 2010a).

The Tyligul fauna (500-410 ka, MIS 12) is typical of Pleistocene loess deposits (Table 2). An exception is the presence of Oxyloma (Succinea) elegans, which reflects particular palaeo-geomorphological conditions, often being found on floodplains. Pupilla sterri, which is present at all other cold stages of the Middle and Late Pleistocene, was not found in the Tyligul set. In general, the fauna is represented mainly by open-habitat species (Vertigo parcedentata, Pupilla muscorum, $P$. triplicata, Vallonia tenuilabris). Its bulk is composed of mesoand xerophiles. There is a large group of cryophilic species (Columella columella, Vallonia tenuilabris, Vertigo parcedentata). This assemblage was characteristic of the Pleistocene cold steppe (tundra-steppe; Kunytsia, 2007). Despite the absence of pronouncedly shade-loving species, it included such species as Euconulus fulvus and Pseudotrichia rubiginosa which prefer forested or partially shaded wet habitats. Sometimes they inhabit dry habitats, but still with moderately rich vegetation (Moine et al., 2005). Pseudotrichia rubiginosa is also classified as a psychrophile, inhabiting mostly wet or moist forests.

Mainly cold-loving and cold-resistant species of open dry habitats (Table 2) are typical of the Dnieper Stage (180-127 ka, MIS 6, Saalian): Vertigo parcedentata, Columella columella, Pupilla muscorum, P. sterri, P. triplicata, P. loessica, Vallonia tenuilabris, Xerolenta obvia (= Helicella candicans), Helicopsis striata. Psychro- and hygrophiles are represented by Vertigo genesii (Alexandrowicz et al., 2014) and Zonitoides nitidus (Melnychuk, 2004).

Pseudotrichia rubiginosa, which was present at all other cold stages of the Pleistocene, is absent from the Dnieper assemblages. However, here for the first time appears Helicopsis striata, which is present in all subsequent cold stages. It is not known from earlier cold stages, but in the Middle Dniester the species also appears in the Middle Pleistocene assemblages of the warm Zavadivka time.

According to Melnychuk (2004), Pupilla loessica and Zonitoides nitidus have been found in the Dnieper deposits, and are known also from the Bug loesses. According to Kunytsia (2007) Pupilla loessica is an index form for the last glaciation. Its rare finds in the deposits of the Dnieper Stage are known from the Dnieper valley (Vasyl'kiv). The species is typical of dry cold Pleistocene stages. It is regarded as an indicator of active aeolian loess accumulation (Ložek, 1964). For a long time, it was considered extinct (Kunytsia, 2007), but now it is known from the recent fauna in the mountainous regions of Central Asia (Ložek, 1986; Meng and Hoffmann, 2009).

Mollusc assemblages of the Tyasmyn Stage (110-104 ka) are relatively species-poor (Table 2). The most characteristic cold-loving mesophiles are Columella columella and Vallonia tenuilabris; xerophiles of open habitats include Pupilla sterri, Helicopsis striata, and Xerolenta obvia (= Helicella candicans). The psychrophile Pseudotrichia rubiginosa is less common. The deposits do not contain the cryophile Vertigo parcedentata, which is present in assemblages of all the other cold stages of the Pleistocene. The xerophile Pupilla triplicata, which was found in the deposits of all the previous cold stages, also disappeared. Later it appears only at the end of the Pleistocene, in the Prychornomorya Stage (see below).

The fauna of the Uday Stage (74-55 ka, MIS 4) is mainly composed of xero- and mesophiles of open habitats, which are often found in other cold periods of the Pleistocene (Table 2). The characteristic cryophylic species are present. Vitrea crystallina, which inhabited the area at that time, is specific for this stage. This is a typical representative of shade-loving group (Alexandrowicz and Alexandrowicz, 2011) and was not detected in the other cold stages. It prefers cool and wet conditions (Moine et al., 2005). The xerophile Helicopsis instabilis appears here for the first time; it also occurs in the following cold stages of the Pleistocene.

Among all other stages of the Pleistocene (cold and warm), the mollusc assemblages of the coldest Bug Stage (27-18 ka, MIS 2) show the greatest taxonomic and ecological diversity (Table 2). Besides the more widespread species, at that time the middle part of the Dniester valley was inhabited by: the cryophiles Columella columella, Vallonia tenuilabris, Vertigo parcedentata; typical species of open habitats Pupilla muscorum, P. loessica, Vallonia excentrica, etc.; the mesophiles Cochlicopa lubrica, Vertigo alpestris, V. arctica, V. pseudosubstriata, Trichia hispida; xerophiles Pupilla sterri, P. triplicata, Chondrula tridens, Xerolenta obvia (= Helicella candicans), Helicopsis striata, Helicopsis instabilis; and the psychro- and hygrophiles Vertigo genesii, Zonitoides nitidus, Pseudotrichia rubiginosa.

Vallonia excentrica, Vertigo arctica and V. pseudosubstriata during the Pleistocene are found only in Bug time; today they inhabit tundra and marshy habitats of Scandinavia, the British Isles and Iceland. Vertigo arctica is also distributed in the Tatra Mountains and the Austrian Alps (Nekola et al., 2018).

Vertigo alpestris has been found in the cold phases of the Bug and Sula time only; V. genesii was found in the deposits of the Bug, Dnieper, and Sula times. Shells of Pupilla muscorum densegyrata in the Middle Dniester region are known only from the Bug Stage, though in general Pupilla muscorum is also characteristic of many cold stages.

Such a great taxomomic, quantitative, ecological, and geographical richness of the fauna during a relatively short time (compared to other cold stages), which was the coldest time in the Pleistocene, deserves special attention. Obviously, in certain palynologicaly established sub-stages (cryo-hygrotic bg $\mathrm{d}_{\mathrm{d}+\mathrm{e}}$ and cryo-xerotic bgf; Gerasimenko, 2010a), when the palaeolandscapes changed significantly, some mollusc assemblages were replaced by others. Such a diversity of molluscs reflects the landscape-climate changes of the Bug Stage.

Some relict cryophiles survived to the Prychornomorya Stage (15-10 ka, MIS 2; Table 2). The proportion of hydrophiles and mesophilous forest-dwellers increased. Clausilia dubia, Cl. bidentata, Arianta arbustorum, which are associated with coldstorms (Moine, 2005), appear for the first time in the cold stages. Nesovitrea hammonis, which was known from Sula time, reappears. 
Changes in the species diversity of major molluscs during the cold stages of the Pleistocene in the Middle Dniester area (after Kunytsia, 1965, 1966, 1971, 1974, 1984, 2007; Motuz 1977, 1982, 1987; Melnychuk, 1984, 2004; Dmytruk, 2004; Ivchenko, 2010; Bogucki et al., 2011, 2012; Alexandrowicz et al., 2014)

\begin{tabular}{|c|c|c|c|c|c|c|c|c|c|c|}
\hline \multirow{2}{*}{ Species } & \multirow{2}{*}{$\begin{array}{l}\text { Ecolog. } \\
\text { group }\end{array}$} & \multicolumn{9}{|c|}{$\begin{array}{l}\text { Terrestrial snails in deposits of cold stages } \\
\text { of the Middle and Late Pleistocene }\end{array}$} \\
\hline & & pč & bg & ud & ts & dn & or* & tl & $\mathbf{s l}$ & $\mathbf{p r}^{*}$ \\
\hline Succinea oblonga (Drap.) & M & + & + & + & + & + & & + & + & \\
\hline Succinea (Oxyloma) elegans (Risso) & $\mathrm{H}$ & - & - & - & - & - & & + & - & \\
\hline Cochlicopa lubrica (Müll.) & M & - & + & - & - & - & & - & + & \\
\hline Vertigo alpestris Alder & M & - & + & - & - & - & & - & + & \\
\hline Vertigo aff. ronnebiensis (Westerlund) & $\mathrm{F}$ & - & - & - & - & - & & - & + & \\
\hline Vertigo genesii (Gredl.) & $\mathrm{H}$ & - & + & - & - & + & & - & + & \\
\hline Vertigo arctica (Wall.) & M & - & + & - & - & - & & - & - & \\
\hline Vertigo pseudosubstriata (Ložek) & $M$ & - & + & - & - & - & & - & - & \\
\hline Vertigo parcedentata (Sandb.) & 0 & + & + & + & - & + & & + & + & \\
\hline Columella columella (Mart.) & M & + & + & + & + & + & & + & + & \\
\hline Pupilla muscorum (L.) & $\mathrm{O}$ & - & + & - & - & + & & + & + & \\
\hline Pupilla sterri (Voith) & $O(X)$ & + & + & + & + & + & & - & + & \\
\hline Pupilla triplicata (Studer) & $O(X)$ & + & + & - & - & + & & + & + & \\
\hline Pupilla loessica Ložek & $\mathrm{O}$ & - & + & - & - & + & & - & - & \\
\hline Vallonia pulchella (Müll.) & O & - & - & - & - & - & & - & + & \\
\hline Vallonia enniensis (Gredl.) & $\mathrm{H}$ & - & - & - & - & - & & - & + & \\
\hline Vallonia excentrica Sterki & $\mathrm{O}$ & - & + & - & - & - & & - & - & \\
\hline Vallonia tenuilabris(Al. Br.) & $\mathrm{O}$ & + & + & + & + & + & & + & + & \\
\hline Chondrula tridens (Müll.) & $O(X)$ & + & + & + & - & + & & - & + & \\
\hline Vitrea crystallina (Müll.) & $F(B)$ & - & - & + & - & - & & - & - & \\
\hline Nesovitrea hammonis (Ström) & M & + & - & - & - & - & & - & + & \\
\hline Nesovitrea petronella (L. Pfeiffer) & M & - & - & - & - & - & & - & + & \\
\hline Zonitoides nitidus (Müll.) & $\mathrm{H}$ & - & + & - & - & + & & - & - & \\
\hline Euconulus fulvus (Müll.) & M & + & - & + & - & - & & + & + & \\
\hline Clausilia bidentata (Ström) & $\mathrm{F}$ & + & - & - & - & - & & - & - & \\
\hline Clausilia dubia (Drap.) & M & + & - & - & - & - & & - & - & \\
\hline $\begin{array}{l}\text { Xerolenta obvia (Menke) (=Helicella } \\
\text { candicans (L. Pfeiffer) }\end{array}$ & $x$ & + & + & + & + & + & & + & + & \\
\hline
\end{tabular}


Tabl. 2 cont.

\begin{tabular}{|c|c|c|c|c|c|c|c|c|}
\hline Helicopsis striata (Müll.) & $O(X)$ & + & + & + & + & + & - & - \\
\hline Helicopsis instabilis (Ross.) & $\mathrm{x}$ & + & + & + & - & - & - & - \\
\hline Pseudotrichia rubiginosa (Al.Schm.) & $M(H)$ & + & + & + & + & - & + & + \\
\hline Trichia hispida (L.) & $\mathrm{M}$ & + & + & + & - & - & - & - \\
\hline Arianta arbustorum (L.) & $F(B)$ & + & - & - & - & - & - & - \\
\hline
\end{tabular}

* the deposits of these stages were not found in the Middle Dniester region

Ecological groups (after Alexandrowicz and Alexandrowicz, 2011): O - species of open biotopes, $F(B)$ - species of shaded biotopes, $\mathrm{M}$ - mesophilic species, $\mathrm{H}$ - hygrophilic species, $\mathrm{X}$ - xerophilous species.

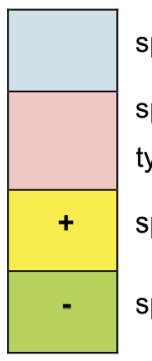

species typical of all cold stages of the Middle and Late Pleistocene species commonly present in mollusc assemblages of some cold stages of the Middle and Late Pleistocene, but not typical of all of them

species is present only in some cold stages of the Middle and Late Pleistocene

species absent only from some cold stages of the Middle and Late Pleistocene

\section{MALACOFAUNAS OF THE WARM STAGES OF THE MIDDLE AND LATE PLEISTOCENE AND THEIR DIVERSITY}

Compared with the cold stages, the mollusc assemblages of warm stages differ more among themselves. The assemblages of the last warm stages, Pryluky, Vytachiv, and Dofinivka (Table 1), are richer in species. The latter is distinct in having relic cryophilic species.

The assemblages of the Martonosha Stage (780-650 ka, MIS 19-17) are species-poor (Table 3). Besides the ubiquitous forms, Vallonia pulchella and Chondrula tridens, representing open dry habitats and widespread in the warmer stages, were found.

Inhabitants of open dry habitats (Pupilla muscorum, Vallonia pulchella, V. costata, Chondrula tridens, Xerolenta obvia (= Helicella candicans) are characteristic of the Lubny Stage (600-500 ka, MIS 15-13). The meso- and psychrophiles are represented only by Carychium minimum and Punctum pygmaeum; this suggests that during this period, the area was inhabited by species of warm steppes and only the last two species provide evidence of periods of higher humidity (Table 3 ).

According to Gerasimenko (2010a), the Lubny Stage consists of three sub-stages: two of these were moderately warm, with a significant southward expansion of forests (sometimes up to the steppe boundary), and a cold interval separating them. However, by the end of each warm sub-stage, forests were replaced by meadow-steppe landscapes. The ecological composition of the assemblages which inhabited the Middle Dniester valley at that time indicates longer dry phases, as shown by the presence of numerous dry-loving species. At the same time, it cannot be ruled out that the deposits of wetter stages with their fauna were simply not preserved, or have not been found yet, since cold-loving species in the fauna are also absent, and in sub-stage $\mathrm{lb} 2$, along with the formation of thin loess/loam in sub-periglacial landscapes, two generations of primary ground vines had also developed (Gerasimenko, 2010a). Therefore, the existing mollusc materials of the Lubny Stage should be revised.

In Zavadivka time (410-250 ka, MIS 11-7) the area was inhabited mainly by open-ground species (Euomphalia strigella), as well as xerophiles: Pupilla sterri, Helicopsis striata, and Helix lutescens. Aegopinella nitens and Helix pomatia represent species of forest or well-shaded habitats. The mesophile Trichia hispida, widespread in the warm stages of the Pleistocene, was also present. Vallonia pulchella and Chondrula tridens, characteristic of the other warm stages, are absent from the deposits of the Zavadivka and Dofinivka stages. These species prefer open and dry habitats; other members of this ecological group are characteristic. The species composition of the these stages is significantly different since in the Dofinivka there is a significant proportion of cryophiles, which are not found in the Zavadivka (Table 3).

The deposits of the Kaydaky Stage (130-110 ka, MIS 5e) contain mainly species which are typical of most of the warm stages of open dry habitats: Vallonia pulchella, Chondrula tridens, Xerolenta obvia (= Helicella candicans). Vallonia costata represents the same ecological group, but it is less common in the warm stages (only in the Lubny and Kaydaky). The hygrophile Succinea (Oxyloma) elegans, which lives in wet habitats close to water, was found only in the deposits of the Kaydaky Stage. Its presence suggests floodplain conditions during deposition at those localities (Table 3).

The assemblage of the Pryluky Stage (104-74 ka, MIS 5a-c) is the richest in species among the warm stages (Table 3). It is also diverse in its ecological composition. The typical representatives of the light-loving and xerophilous fauna are Pupilla sterrii, Vallonia pulchella, Chondrula tridens, Xerolenta obvia (= Helicella candicans), Helicopsis striata. The group of shade-loving forms is also numerous: Clausilia dubia, Vitrea diaphana, Arianta arbustorum, Cepaea aff. nemoralis, Helix pomatia. The association of this warm stage also includes the 
Changes in the species diversity of major molluscs during warm Pleistocene stages in the Middle Dniester area (after Kunytsia, 1965, 1966, 1971, 1974, 1984, 2007; Motuz, 1977, 1982, 1987; Melnychuk, 1984, 2004; Dmytruk, 2004; Ivchenko, 2010; Bogucki et al., 2011, 2012; Alexandrowicz et al., 2014)

\begin{tabular}{|c|c|c|c|c|c|c|c|c|c|}
\hline \multirow{2}{*}{ Species } & \multirow{2}{*}{$\begin{array}{l}\text { Ecolog. } \\
\text { group }\end{array}$} & \multicolumn{8}{|c|}{$\begin{array}{l}\text { Terrestrial snails in deposits of warm stages } \\
\text { of the Middle and Late Pleistocene }\end{array}$} \\
\hline & & df & vt & pl & kd & $\mathbf{p t}^{\star}$ & zv & lb & $\mathrm{mr}$ \\
\hline Carichium minimum & & - & - & - & - & & - & + & - \\
\hline Succinea oblonga (Drap.) & M & + & + & + & + & & + & + & + \\
\hline Succinea (Oxyloma) elegans (Risso) & $\mathrm{H}$ & - & - & - & + & & - & - & - \\
\hline Vertigo parcedentata (Sandb.) & $\mathrm{O}$ & + & - & - & - & & - & - & - \\
\hline Columella columella (Mart.) & M & + & - & - & - & & - & - & - \\
\hline Pupilla muscorum (L.) & $\mathrm{O}$ & - & + & - & - & & - & + & - \\
\hline Pupilla sterri (Voith) & $O(X)$ & + & + & + & - & & + & - & - \\
\hline Vallonia pulchella (Müll.) & $\mathrm{O}$ & - & + & + & + & & - & + & + \\
\hline Vallonia costata (Müll.) & $\mathrm{O}$ & - & - & - & + & & - & + & - \\
\hline Vallonia tenuilabris (Al. Br.) & $\mathrm{O}$ & + & - & + & - & & - & - & - \\
\hline Chondrula tridens (Müll.) & $O(X)$ & - & + & + & + & & - & + & + \\
\hline Cochlodina laminata (Montagu) & $\mathrm{F}$ & + & - & - & - & & - & - & - \\
\hline Clausilia parvula Férussac & M & - & + & + & - & & - & - & - \\
\hline Clausilia dubia (Drap.) & $\mathrm{F}$ & + & + & + & - & & - & - & - \\
\hline Laciniaria plicata (Drap.) & M & + & - & - & - & & - & - & - \\
\hline Punctum pygmaeum (Drap.) & M & - & - & - & - & & - & + & - \\
\hline Vitrea diaphana (Studer) & $\mathrm{F}$ & - & + & + & - & & - & - & - \\
\hline Aegopinella nitens (Michaud) & $\mathrm{F}$ & - & - & - & - & & + & - & - \\
\hline $\begin{array}{l}\text { Xerolenta obvia (Menke) (=Helicella candicans } \\
\text { (L. Pfeiffer) }\end{array}$ & $x$ & + & + & + & + & & - & + & - \\
\hline Helicopsis striata (Müll.) & $O(X)$ & + & + & + & - & & + & - & - \\
\hline Pseudotrichia rubiginosa (Al.Schm.) & $M(H)$ & + & - & - & - & & - & - & - \\
\hline Trichia hispida (L.) & $M$ & + & + & + & - & & + & - & - \\
\hline Euomphalia strigella (Drap.) & $\mathrm{O}$ & - & - & - & - & - & + & - & - \\
\hline Arianta arbustorum (L.) & $F(B)$ & + & + & + & - & & - & - & - \\
\hline Cepaea aff. nemoralis(L.) & $F(B)$ & - & - & + & - & & - & - & - \\
\hline Helix pomatia (L.) & $F(B)$ & - & - & + & - & & + & - & - \\
\hline Helix lutescens (Ross.) & $O(X)$ & - & - & - & - & & + & - & - \\
\hline
\end{tabular}

* deposits of these stages have not been found in the Middle Dniester region 
Tabl. 3 cont.

Ecological groups (after Alexandrowicz and Alexandrowicz, 2011): O - species of open biotopes, $F(B)$ - types of shaded biotopes, $\mathrm{M}$ - mesophilic species, $\mathrm{H}$ - hygrophilic species, $\mathrm{X}$ - xerophilous species.

species typical of all warm stages of Pleistocene

species commonly present in mollusc assemblages of some warm stages of the Pleistocene, but not typical to all of them species present only in some warm stages of the Pleistocene

species absent from only some warm stages of the Pleistocene

Pleistocene cryophile Vallonia tenuilabris. Trichia hispida and Clausilia parvula represent the mesophilous group. The specificity of the assemblage of the Pryluky Stage is the presence of the mesophile Clausilia parvula. In the Middle Dniester region, it is known only from the next warm Vytachiv Stage. At present, the species inhabits Western and Central Europe, but the distribution range reaches the fringes of the Western Carpathians. It has been found and studied in detail in Poland, where it belongs among rare modern species (Maltz, 1999; Pokryszko et al., 2004; Pokryszko and Cameron, 2005). It is a mesophile, petrophile and calciphile (Pokryszko and Maltz, 2007). It is characteristic of open, moderately moist areas, and is often found in rocky habitats, especially on vegetation-covered limestone and rarely in forest leaf-litter. At present, this species does not live in Ukraine (Likharev, 1962).

The fauna of the Vytachiv Stage (55-27 ka, MIS 3) is also quite rich in species (Table 3 ). The greatest proportion is formed by dry-loving species of open areas: Pupilla muscorum, $P$. sterri, Vallonia pulchella, Chondrula tridens, Xerolenta obvia (= Helicella candicans), Helicopsis striata. Shade-loving species (Clausilia dubia, Vitrea diaphana, Arianta arbustorum) and mesophiles (Clausilia parvula, Trichia hispida) also constitute a significant proportion of the assemblage. Most of the species listed are typical of the warm Pleistocene stages.

The deposits of the short Dofinivka Stage (18-15 ka, MIS 2), hold many cold-loving species (Vertigo parcedentata, Columella columella, Vallonia tenuilabris) which are not characteristic of warm periods. Xerophiles of open areas are represented by Pupilla sterrii, Xerolenta obvia (= Helicella candicans) and Helicopsis striata. The shade-loving group forms a considerable proportion: Cochlodina laminata, Clausilia dubia, Arianta arbustorum; the same is true of meso- and psychrophiles Laciniaria plicata, Trichia hispida, Pseudotrichia rubiginosa (Table 3). The assemblage is quite diverse for the rather short duration of the Dofinivka Stage. It indicates that at that time the climate conditions and landscapes in the region of the Middle Dniester often changed. In different sections, deposits of the stage are represented by steppe-type brown soils, chernozem-like soils, and grey forest soils. In the section close to Koropets village (Figs. 1 and 2), two soils can be traced: a lower chernozem and an upper grey forest soil, which are separated by inter-soil loams containing cold-loving fauna (Kunytsia, 1974).

The mollusc assemblages and the deposits of the Dofinivka Stage are a vivid example of Pleistocene environmental-climate changes, that could lead to a drastic change of landscapes within rather short time intervals, and of how the mollusc fauna, as an excellent ecological indicator, reacted to these changes by replacing of some species (assemblages) with others. A sim- ilar phenomenon can be observed in the Holocene, when during 12 ky the environmental conditions changed repeatedly. Analysing the late stages of the Pleistocene, and the nature and frequency of these changes, the question arises: "Could such changes have taken place during the more ancient stages of the Pleistocene, which lasted 50-100 ky?" To answer this, it is necessary to study in detail the depositional sequence of such stages, the sequence and changes in their succession, facies variability and, crucially, to sample molluscs strictly in accordance with the morphological characteristics of the deposits. This methodological approach should make it possible to avoid artificially "mixed" assemblages and to reconstruct the natural conditions at the level of stages and sub-stages more precisely.

\section{DISCUSSION}

A "mixed" character (Kunytsia, 2007) is commonly regarded as a specific feature of the Pleistocene land snail faunas of the Middle Dniester and Ukraine. This shows the presence of species from different ecological groups, which today do not co-occur, in one mollusc assemblage. In our opinion, such mixed assemblages should be interpreted as a result of the diversity of different stages of the Pleistocene. It is misleading to try to combine them while reconstructing a single landscape, since they include species characteristic of different natural zones. The "mixed fauna" is a sign of a mixed taphocoenosis rather than a feature which could distinguish Pleistocene mollusc assemblages from modern ones. The molluscs lived in different habitats but were buried together in sediments of the same stratigraphic unit. Their mixing in the taphocoenosis should be considered as evidence of short-term intervals of climate change which could lead to changes in faunal assemblages. Even during the Holocene, there were short warm/cold, dry/wet intervals (Gerasimenko, 2010b), which led to landscape changes. Such malacocoenoses could also exist at various stages of the Pleistocene. The mixed assemblages should be interpreted as representing a succession following each climate change rather than representing faunas of the whole stage. This is the approach we used in this paper. To avoid the bias of "mixed faunas" in the study of Pleistocene molluscs, sampling should be done with references to well-defined stratigraphic units and must be supported by accompanying methods (palynological, palaeopedological, radiocarbon, etc.).

A critical approach to palaeoecological reconstructions of the Pleistocene for mollusc faunas, which are indicators not only of palaeoclimatic, but also of palaeoenvironment conditions, is necessary. Why the "palaeoenvironment"? In some cases, it is impossible to interpret the environmental tolerances 


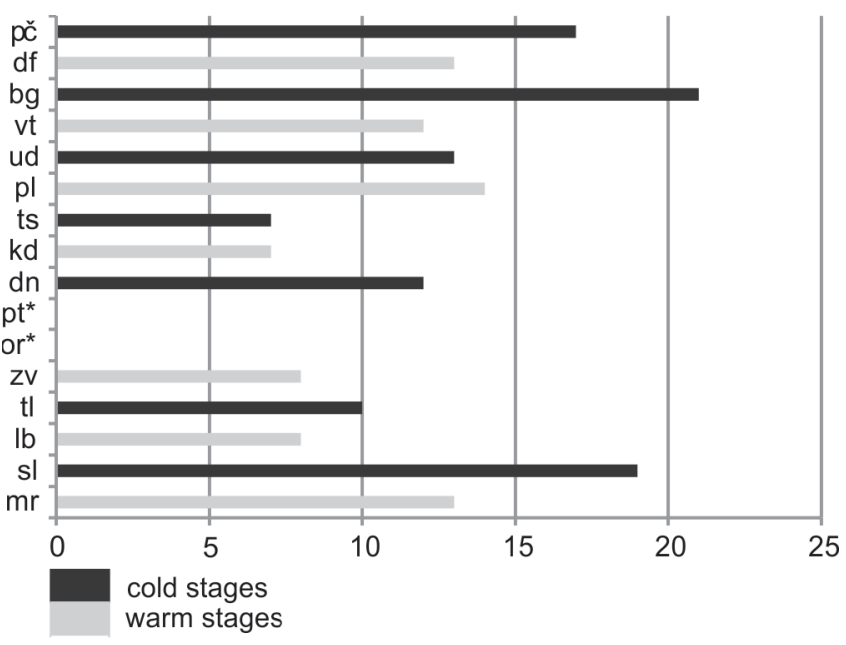

Fig. 2. Number of terrestrial mollusc species in the Middle and Late Pleistocene stages in the Middle Dniester area

Horizontally: number of species; vertically: Pleistocene stages (see the indices in Table 1); * - stages not recorded in the area studied

of certain species of molluscs based on climate conditions, as this is controversial. This is especially true of Columella columella. It is a mesophile, but it is not suitable for reconstructions of humidity levels. As noted by Rousseau (2001), although the Pleistocene Pupilla assemblages indicate low precipitation with intense evaporation, and the Columella assemblage implies low precipitation with almost no evaporation, the recent $C$. columella lives in a tundra-mountainous environment in Scandinavia, with annual precipitation of $300-473 \mathrm{~mm}$. Even though this amount of precipitation is low, the habitats stay damp due to the low evaporation, which keeps the rocks moist and the landscapes waterlogged. Therefore, we consider it misleading to use C. columella to interpret the level of precipitation, and we regard this species only as an indicator of cold conditions.

For a more complete interpretation of mollusc faunas in different stages of the Pleistocene, of their species composition and their spatial distribution, one would need to trace them along specific stratigraphic horizons and between different localities of the Middle Dniester valley, as has been done, for example, for the site of Bullendorf in NE Austria (Carobene et al., 2018). However, due to a present lack of original material, it is not yet possible to so compare the sections studied by Kunytsia with new sections both from the valley of the Middle Dniester and with sites in the rest of Ukraine and Europe.

Mollusc assemblages varied among different warm and cold stages largely because of different landscape and climatic conditions, with extreme values of temperatures and humidity varying within individual stages. Relief also played an important role, especially slope exposure. In the study area, the Pleistocene deposits are best preserved in the Dniester valley, and mollusc faunas were obtained by Kunytsia and other researchers only from the terrace sections. Molluscan species diversity within individual palaeogeographical stages may also have been influenced by sedimentary conditions (subaerial or subaquatic) and the distance from the river channel (low floodplain, high floodplain, low, medium, or high terrace). This factor could primarily affect the presence or absence in the mollusc assemblages of moisture-sensitive species. River valleys, especially deeply incised, are also characterized by significant landscape differentiation, commonly related to the distance from the river. Even in a dry climate in the region, meso- and hygrophilous species of molluscs can live on floodplains.

Despite the species composition diversity of the molluscan fauna in different stages of the Pleistocene of the Middle Dniester, the dominance of some species can be recognised. Succinea oblonga (Drap.) was found in all stages of the Pleistocene. The following species are also characteristic of the cold stages: Columella columella (Mart.), Vallonia tenuilabris (Al.Br.), Xerolenta obvia (Menke) [= Helicella candicans (L. Pfeiffer)). The last of these species is also found in the deposits of almost all warm stages, except for Martonosha and Zavadivka. Apparently, Xerolenta obvia (Menke) [= Helicella candicans (L. Pfeiffer)] was quite plastic to the temperature conditions during the Pleistocene providing the climate relatively arid (as a xerophilous species)]. The cryophilic species of cold climatic cycles have been found in the deposits of only some warm stages: Columella columella (Mart.) only in Dofinivka time, and Vallonia tenuilabris (Al. Br.) in Pryluky and Dofinivka times. The presence of these and some other cryophilic species and in particular, Vertigo parcedentata (Sandb.) was explained by Kunytsia (2007) in terms of complex transitions in time and space between the cold and warm stages of the Pleistocene, which was reflected in the formation of mixed, heterogeneous faunal assemblages.

Dominant species of the cold stages include Vertigo parcedentata (Sandb.), Pupilla sterri (Voith), Helicopsis striata (Müll.) and Pseudotrichia rubiginosa (Al. Schm.), which are characteristic of most, though not all, cold stages. The following species are also quite common: Pupilla triplicata (Studer), Chondrula tridens (Müll.) and Euconulus fulvus (Müll.). Helicopsis instabilis (Rossmässler) and Trichia hispida (L.), characteristic of the last cold stages (Uday, Bug and Prychornomoria). The presence of the latter two species in earlier cold climatolithes seems not to have been noted (Kunytsia, 1965, 1966, 1971, 1974, 1984, 2007; Motuz, 1977, 1982, 1987 ; Melnychuk, 1984, 2004; Dmytruk, 2004; Ivchenko, 2010; Bogucki et al., 2011, 2012; Alexandrowicz et al., 2014).

Groups of molluscs of warm Pleistocene climatolithes of the Middle Dniester differ significantly in species composition, so fewer dominant species are found here. Succinea oblonga (Drap.), noted above, is found at all stages. Taxa such as Vallonia pulchella (Müll.) and Chondrula tridens (Müll.) have not been identified only for the Zavadika and Dofinivka stages. Quite common are Pupilla sterri (Voith), Clausilia dubia (Drap.), Xerolenta obvia (Menke) (= Helicella candicans (L. Pfeiffer), Helicopsis striata (Müll.), Trichia hispida (L.), Arianta arbustorum (L.), but these taxa are not characteristic of all stages.

The following taxa are moderately rare in the Upper and Middle Pleistocene deposits of the Middle Dniester Valley: Vallonia excentrica Sterki, Vertigo arctica (Wall.), V. pseudosubstriata Ložek, Cochlodina laminata (Montagu), Clausilia bidentata (Ström), Laciniaria plicata (Drap.), Punctum pygmaeum (Drap.), Vitrea crystallina (Müll.), Aegopinella nitens (Michaud), Nesovitrea petronella (L. Pfeiffer), Euomphalia strigella (Drap.).

In general, biostratigraphic analysis of the Pleistocene molluscs of the Middle Dniester showed that the mollusc assemblages of the cold stages are more diverse than in the warm stages (Fig. 2). The highest species diversity was established for the Bug climatolith. It is also high for the Sula and Prychornomoria stages. Among the warm stages, the highest species diversity is characteristic for the last three: Pryluky, Vytachiv and Dofinivka. For both cold and warm stages, high species diversity is observed at the end of the Pleistocene (Pryluky-Prychornomoria stages). 


\section{CONCLUSIONS}

Analysis of mollusc faunas from different stages of the Pleistocene in the Middle Dniester area shows that the species and ecological composition of the assemblages vary from stage to stage. The differences in the assemblages' species composition reflect the spatial and temporal changes of the palaeolandscapes and as well as global and local climate changes. Accordingly, each stage of the Pleistocene has its own individual taxonomic and ecological set of species.

The mollusc assemblages of those stages in which the environmental conditions were particularly changeable are more varied. The changes involved two factors - air temperature (warm/cold phases) and humidity (wet/dry). Such changes, in the first place, led to landscape changes and, consequently, affected the species composition and ecology of the mollusc faunas, which now makes it possible to interpret those changes.

Analysing the fauna of the cold and warm stages of the Pleistocene, we found that the latter were more diverse. While during the cold stages there were many species in common for all or most stages, the faunas of the warm stages were more varied. Such a feature can play an important role in Quaternary biostratigraphy.

The biodiversity and specific features of the Middle Dniester mollusc assemblages facilitate understanding of the evolution of environmental conditions during the Pleistocene and make it possible to identify individual environmental events reflected by responses among the mollusc communities. These results can serve as a powerful instrument in regional palaeogeographic analysis.

Acknowledgements. This work was partly supported by INQUA project 1606P "Ground squirrels on the march: expansion and speciation in the Quaternary of the Circum-Pontic area and surroundings". We thank two anonymous reviewers for their constructive review of the manuscript. We extend our gratitude to B. Pokryszko for proofreading the text.

\section{REFERENCES}

Alexandrowicz, S.W., Alexandrowicz, W.P., 2011. Analiza malakologiczna. Metody badań i interpretacji (in Polish). Rozprawy Wydziału Przyrodniczego PAU, 3.

Alexandrowicz, W.P., 2015a. The application of malacological analysis in the study of slope deposits: late Pleistocene and Holocene of the Podhale Basin (Carpathians, Poland). Acta Geologica Polonica, 65: 247-263.

Alexandrowicz, W.P., 2015b. Malakofauna stanowisk paleolitycznych strefy pery- i metakarpackiej (in Polish). In: Paleolityczna ekumena strefy pery- i metakarpackiej (eds. M. Łanczont and T. Madeyska): 577-595. Wyd. UMCS, Lublin.

Alexandrowicz, W.P., Lanczont, M., Boguckyj, A.B., Kulesza, P., Dmytruk, R., 2014. Molluscs and ostracods of the Pleistocene loess deposits in the Halych site (Western Ukraine) and their significance for palaeoenvironmental reconstructions. Quaternary Science Reviews, 105: 162-180.

Ambrojevici, C., 1932. Zur Landenshenkenfauna des nordbessarabischen Endneolithikums. Buletinul Facultaţii de Stinte din Cernauţi, 1: 251-256.

Ambrojevici, C., 1938. Materialien zur Molluskenfauna der pleistound holozänen Ablagerungen Nordrumaniens. Buletinul Museului Regional al Basarabiei din Chisinau, 9: 40-100.

Anisyutkin, N.K., 2013. Mustierskaya stoyanka Kietrosy v kontekstie sredniego paleolita Vostochnoy Evropy (in Russian). Nestor-Historia, Sankt-Petersburg.

Bąkowski, J., 1880. Mięczaki zebrane na Podolu w lipcu i sierpniu r.1879 (in Polish). Sprawozdanie Komisji Fizjograficznej, 14: 62-76.

Bąkowski, J., 1881. Mięczaki zebrane na Podolu na stepie Pantalichy i w Toutrach w r. 1880 (in Polish). Sprawozdanie Komisji Fizjograficznej, 15: 220-232.

Bąkowski, J., 1884. Mięczaki galicyjskie (in Polish). Kosmos, 9: 190-197, 275-283, 376-391, 477-490, 604-611, 680-697, 761-789.

Bąkowski, J., 1885. Utwór dyluwialny między Koropcem a dolnym biegiem Strypy na Podolu (in Polish). Kosmos, 10: 398-405.

Bąkowski, J., 1891. Mięczaki (Mollusca) (in Polish). Wyd. Muzeum im. Dzieduszyckich, Lwów.

Berg, L., 1947. Klimat i zhyzn' (in Russian). Gosudarstvennoe izdatelstvo geograficheskoy literatury, Moscow.

Bogucki, A., Dmytruk, R., Dumas, l., 2011. Pryrodni umovy chasu formuvannia dubnivs'kogo vykopnogo gruntu Halyts'kogo Prydnisteria (in Ukrainian). Visnyk Lvivskogo Universytetu. Seria Geografichna. 39: 35-43.
Bogucki, A., Jacyshyn, A., Dmytruk, R., Tomeniuk, O., Zavalij, D., Lanczont, M., 2012. High terraces of the Dnister river at environs of the village Dovhe (in Ukrainian with English summary). Visnyk Lvivskogo Universytetu. Seria Geografichna, 40: 123-131.

Bondarchuk, V., 1933. Do kharakterystyky kopalnykh miakuniv z chetvertynnykh pokladiv Ukrainy (in Ukrainian). Chetvertynnyi Period, 5: 15-33.

Bondarchuk, V., 1969. Lessovyye kompleksy yugo-zapadnoy chasti Vostochno-Evropeyskoy ravniny (in Russian). In: Materialy po Chetvertichnomu Periodu Ukrainy (ed. V. Bondarchuk): 9-20. Naukova Dumka, Kyiv.

Carobene, D., Harzhauser, M., Mandic, O., Gatto, R., 2018. Taxonomy and paleoecology of continental Gastropoda (Mollusca) from the late Pleistocene mammoth-bearing site of Bullendorf in NE Austria. Rivista Italiana di Paleontologia e Stratigrafia, 124: 509-534.

Danilovsky, I., 1940. Rukovodiashchiye chetvertichnyye molluski zapadnoy polosy Evropeyskoy chasti SSSR (in Russian). Sovetskaya Geologia, 5-6: 103-111.

Danilovsky, I., 1961. Istoriya chetvertichnykh molluskov SSSR i ikh znacheniye dlia stratigrafii chetvertichnykh otlozheniy (in Russian). Informatsionnyi Sbornik VSEGEI, 47: 75-96.

Dmytruk, R.Y., 2001. Reconstruction of conditions of accumulation of the lower subhorizon of the upper horizon of the Upper Pleistocene forests of Volyn-Podillya (according to malacofauna) (in Ukrainian with English summary). Naukovi Zapysky Vinnytskogo Universytetu, 2: 38-42.

Dmytruk, R.Y., 2002. The nature of changes in the quantitative composition of the malacofauna and its relationship with climatic conditions (in Ukrainian with English summary). Visnyk Zhytomyrskogo Universytetu imeni Ivana Franka, 10: 206-209.

Dmytruk, R., 2004. Hight Pleistocene fauna of molluscs of the Palaeolithic site Molodove $V$ and its paleogeographic interpretation (in Ukrainian with English summary). Visnyk Lvivskogo Universytetu, Seria Geograficzna. 30: 104-110.

Dunikowski, E., 1880. Przyczynek do znajomości galicyjskiego dyluwijum (in Polish). Kosmos, 5: 6-28.

Friedberg, W., 1906. Tekst do zeszytu 19. Sambor. Atlas geologiczny Galicji (in Polish). Kraków.

Gerasimenko, N.P., 2010a. Korelatsiya korotkoperiodychnych etapiv pleistotsenu za paleolandshavtnymy danymy (in Ukrainian). In: Prostorovo-chasova koreliatsiya paleogeografichnyh umov chetvertynnogo periodu na terytoriyi Ukrainy (ed. Zh. Matvijishyna): 104-129. Naukova Dumka, Kyiv. 
Gerasimenko, N.P., 2010b. Korotkoperiodychna etapnist rozvytku landshaftiv u golotseni (in Ukrainian). In: Prostorovo-chasova koreliatsiya paleogeografichnyh umov chetvertynnogo periodu na terytoriyi Ukrainy (ed. Zh. Matvijishyna ): 159-165. Naukova Dumka, Kyiv.

Ivanova, I., Popov, G., 1961. Novyye dannyje o vozrastie vysokikh dnestrovskikh teras $v$ sviazi s nakhodkami fauny molluskov (in Russian). Doklady AN SSSR, 136: 1425-1427.

Ivchenko, A.S., 2010. Mizhregionalna koreliatsiya paleogeografichnykh umov za paleontologichnymy danymy (in Ukrainian). In: Prostorovo-chasova koreliatsiya paleogeografichnyh umov chetvertynnogo periodu na terytoriyi Ukrainy (ed. Zh. Matvijishyna): 76-94. Naukova Dumka, Kyiv.

Kulakovska, L., Usik, V., Haesaerts, P., Ridush, B., Uthmaier, Th., Hauk, Th., 2015. Upper Paleolithic of Middle Dniester: Doroshivtsi III site. Quaternary International, 359-360: 347-361.

Kunytsia, M.O., 1965. Do pytannia pro budovu i umovy utvorennia terasovykh vidkladiv Seredniogo Dnistra (in Ukrainian with English summary). In: Geomorfologia richkovykh dolyn Ukrainy (ed. M.F. Veklitch): 69-77. Naukova Dumka, Kyiv.

Kunytsia, M.O., 1966. Zminy fauny moliuskiv pleistotsenu i kholotsenu Ukrainy ta yiyi stratygraficzhne znachennia (in Ukrainian). In: Paleogeografichni umovy terytoriyi Ukrainy v pliotseni ta antropogeni (eds. M.F. Veklitch and G.I. Moliavko): 38-48. Naukova Dumka, Kyiv.

Kunytsia, M.O., 1971. Ranniepleistotsenovaya fauna nazemnykh i presnovodnykh molluskov Sredniego Dniestra (in Russian). Paleontologicheskii Sbornik, 8: 34-41.

Kunytsia, M.O., 1974. Stratigrafia i malakofauna pleistotsena Ukrainy (in Russian with English summary). Chernivtsi Univ., Chernivtsi.

Likharev, I.M., 1962. Clausiliidae Ukrainy. Fauna SSSR. Molluski. 3 (4) (in Russian). Izdatelstvo AN SSSR, Moskva-Leningrad.

Limondin-Lozouet, N., Preece, R.C., 2014. Quaternary perspectives on the diversity of land snail assemblages from northwestern Europe. Journal of Molluscan Studies, 80: 224-337.

Lisiecki, L.E., Raymo, M.E., 2005. A Pliocene-Pleistocene stack of 57 globally distributed benthic $\delta^{18} \mathrm{O}$ records. Paleoceanography, 20, PA 1003, doi:10.1029/2004PA001071

Łomnicki, M., 1886. Mięczaki znane dotychczas z pleistocenu galicyjskiego (in Polish). Kosmos, 11: 276-299.

Łomnicki, A., 1887. Żwiry starodyluwialne na Podolu galicyjskiem (in Polish). Kosmos, 12: 436

Łomnicki, A., 1900. Atlas geologiczny Galicyi. Text do zesz. 12 (in Polish). Kraków.

Łomnicki, A.M., 1908. Mięczaki iłu pleistoceńskiego, wydobyte ze szybu mamutowego w Staruni (in Polish). Kosmos, 33: 73-76.

Ložek, V., 1964. Quartärmollusken der Tschechoslowakei. Rozpravy Ustředniho Ustavu Geologického, Praha.

Ložek, V., 1986. Quaternary malacology and fauna genesis in Central Europe. Proceedings 8th International Malacology Congress; 1983. Budapest, 143-145.

Lungersgauzen, G., 1933. Novyi poverkh lesu na Ukraini (in Ukrainian). Chetvertynnyi Period, 7: 99-121.

Lungersgauzen, G., 1938. Fauna Dniestrovskikh terass (in Russian). Geologicheskiy zhurnal AN USSR, 5: 199-236.

Maltz, T.K., 1999. Ślimaki (Gastropoda) Kotliny i Pogórza Wałbrzyskiego (in Polish). Folia Malacologica, 7: 51-72.

Melnychuk, I., 1984. Novyye dannyye o faunie molluskov lessovo-pochvennoi tolshchi nizhniego Pridnestrovia i yeyo paleogeograficheskoye znacheniye (in Russian). In: Obshchaya i regionalnaya paleogeografia (ed. M.F. Veklcith): 131-139. Naukova Dumka, Kyiv.

Melnychuk, I., 2004. Paleolandshafty Ukrainy v antropogeni (in Ukrainian). Obrii, Kyiv.

Meng, S., Hoffmann, M.H., 2009. Pupilla loessica Ložek 1954 (Gastropoda: Pulmonata: Pupillidae) - "A Living Fossil" in Central Asia? Eiszeitalter und Gegenwart. Quaternary Science Journal, 58: 55-69.

Moine, O., Rousseau, D-D., Antoine, P., 2005. Terrestrial molluscan records of Weichselian Lower to Middle Pleniglacial climatic changes from the Nussloch loess series (Rhine Valley, Germany): the impact of local factors. Boreas, 34: 363-380.
Motuz, V.M., 1977. O faunie kontinentalnykh molluskov rayona stoyanki Korman IV (in Russian). In: Mnogosloinaya paleoliticheskaya stoyanka Korman IV na Srednem Dniestre (eds. G.I. Goretski and S.M. Tzeitlin): 119-125. Nauka, Moscow.

Motuz, V.M., 1982. Fauna molluskov iz rayona paleoliticheskoy stoyanki Molodova I (in Russian). In: Molodova I. Unikalnoe mustierskoye poselenie na Srednem Dniestre (eds. G.I. Goretski and I.K. Ivanova): 173-188. Nauka, Moscow.

Motuz, V.M., 1987. Nazemnyye molluski iz chetvertichnykh otlozheniy stoyanki Molodova V (in Russian). In: Mnogosloinaya paleoliticheskaya stoyanka Molodovo V (eds. I.K. Ivanova and S.M. Tzeitlin): 162-168. Nauka, Moscow.

Nekola, J.C., Chiba, S., Coles, B.F., Drost, Ch.A., Proschwitz, T., Horsak, M., 2018. A plylogenetic overview of the Genus Vertigo O.F. Muller, 1773 (Gastropoda: Pulmonata: Pupillidae: Vertigininae). Malacologia, 62: 21-161.

Petrbok, J., 1930. Zur Kenntnis der quartären und rezenten Mollusken Bessarabien und Galatz. Archiv für Molluskenkunde, 62: 198-200.

Pokryszko, B.M., Cameron, R.A.D., 2005. Geographical variation in the composition and richness of forest snail faunas in northern Europe. Records of the Western Australian Museum, 68: 115-132.

Pokryszko, B.M., Maltz, T.K., 2007. Rare and endangered terrestrial gastropods of Lower Silesia (SW. Poland) - current status and perspectives. Acta Universitatis Latviensis. Biology, 723: 7-20.

Pokryszko, B.M., Cameron, R.A.D., Maltz, T.K., 2004. Cochlodina costata (C. Pfeiffer, 1828) (Gastropoda: Pulmonata: Clausiliidae) (in Polish). Folia Malacologica, 12:189-192.

Pokryszko, B.M., Cameron, R.A.D., Mumladze, L., Tarkhnishvili, D., 2011. Forest snail faunas from Georgian Transcaucasia: patterns of diversity in a Pleistocene refugium. Biological Journal of the Linnean Society, 102: 239-250.

Polianskyi, Y., 1925. Geologichno-morfologichni pomichannia v rayoni Novosilky Kostiukovoyi (Zalishchyky) i diliuvialna tsyklichna skhema poludnevogo Podillia (in Ukrainian). Zbirnyk Fiziografichnoi komisii Naukovogo Tovarystva Shevchenka, 1: 3-24.

Radzievskyi, V., 1957. Nova znachidka davniochetvertynnykh molliuskiv na Sredniomu Dnistri (in Ukrainian). Dopovidi AN URSR, 6: 591-593.

Radzievskyi, V., 1959. Do kharakterystyky lesovykh porid Seredniogo ta Nyzhniogo Prydnistrovia (in Ukrainian) (in Ukrainian). Geologichnyi Zhurnal AN URSR, 19: 99-103.

Ridush, B., Marchuk, L., 2018. Development of the Dniester valley within Tovtry zone during Pliocene and Early Pleistocene (in Ukrainian with English summary). Naukovyi Visnyk Chernivetskogo Universytetu, Geografia, 803: 96-102.

Rogala, W., 1907. Przyczynek do znajomości dyluwialnich utworów Galicji (in Polish). Kosmos, 32: 350-363.

Rousseau, D.-D., 2001. Loess biostratigraphy: new advances and approaches in mollusk studies. Earth-Science Reviews. 54: 157-171.

Rychlicki, J., 1913. Przyczynek do znajomości dyluwium (in Polish). Kosmos, 38: 769-770.

Teisseyre, W., 1900. Atlas geologiczny Galicyi. Tekst do zeszytu 8 (in Polish). Kraków.

Tomeniuk, O., 2010. Yuriy Polianskyi as a researcher of terraces of Dniester River (in Ukrainian with English summary). Visnyk Lvivskogo Universytetu, Ser. Geogr., 38: 340-356.

Veklitch, M.F., 1961. Molluski chetvertichnykh kontinentalnykh otlozheniy USSR (in Russian). Materialy Vsesoyuznogo soveshchania po izucheniyu chetvertichnogo perioda, 1: 341-346.

Veklitch, M.F., 1982. Paleoetapnost' i stratotipy pochvennykh formatsiy verkhniego kainozoya (in Russian). Naukova Dumka, Kyiv

Velichko, A.A., Faustova, M.A., Pisarea, V.V., Gribchenko, Yu.N. Sudakova, N.G., Lavrentiev, N.V., 2011. Glaciations of the East European Plain: distribution and chronology. Developments in Quaternary Science, 15: 337-359.

Wiśniewski, T., 1908. Atlas geologiczny Galicji. Tekst do zeszytu 21 (in Polish). Kraków. 